Review article

\title{
Key processes shaping the current role and operation of higher education institutions in society
}

\author{
Danuta Piróg \\ Institute of Geography, Pedagogical University of Cracow, Podchorążych Str. 2; 30-084 Kraków Poland \\ E-mail address: mail: dbutryn@up.krakow.pl
}

\begin{abstract}
The concurrent processes of globalisation, computerisation, and integration shape and constantly modify developmental factors and generate multidirectional social changes. Among social life fields, one of them has been particularly sensitive to the impact of those processes and has remained in clear feedback relationship with them is education, including universitylevel education. This article aims to present some reflections on the key processes which influence the environment of higher education institutions' activity and on what their impact specifically is. The factors taken into account include: the transformation of the political and economic system, integration with the European higher education area, the market shift of education, evolving social demands towards higher education institutions and society's attitude towards work. As knowledge has become an asset largely affecting the quality of life of people and society, universities have changed their focus from searching for and exploring truth, good and beauty in the world towards becoming innovation centres, transferring knowledge as offering their educational services. In this article, those trends have been exemplified in relation to geography degree programmes, and shown through an evolution of the model of the university. Based on a review of the literature, it seems that the processes discussed also concern geography degree programmes, and the future operation of these programmes closely depends on whether they can maintain their care for high quality education coupled with genuine efforts to ensure the smooth transition of graduates into the labour market.
\end{abstract}

KEY WORDS: educational service; geography studies; higher education, labour market, models of university

ARTICLE HISTORY: received 14 December 2015; received in revised form 3 March 2016; accepted 14 March 2016

\section{Introduction}

Social and economic development, both local and global, has fundamentally been dependent on the availability of education and employment for the population. Processes such as European integration, globalisation and economic transition have increased the correlation between a person's education level and the quality of job they can hope to obtain, which, in turn, has significantly affected the evolution of universities. Also the recent shift of Poland's economy from the socialist model of a centrally planned economy towards a free market has brought about a farreaching transformation of the concept of higher education, the role institutions play in society, and the university-level teaching approach. As knowledge has become an asset largely affecting people's quality of life, universities have changed their focus from searching for and exploring truth, good and beauty in the world towards becoming innovation centres, transferring knowledge as part of their educational services (see, e.g., DACH, 2008; WOŹNICKI, 2008; GĘSICKI, 2013; PlEWKA, 2013; WoŁK, 2013).

These changes, in terms of their nature and scale, also concern university geography studies, which are closely correlated with the condition of geography itself as an academic discipline (SULIBORSKI \& WóJCIK, 2011). Just as geography, mostly playing a culture-shaping and information role, has been hoping to raise its profile by expanding its technical dimension (LISOWSKI, 2008, 2012), heads of geography faculties have been introducing new concepts and geography teaching curricula in order for their faculties to be able to continue to operate. Alarmingly, the numbers of people willing 
to study geography in Poland do not cease to decrease (TRACZ \& HIBSZER, 2013), despite the education offer being constantly expanded to include new fields of specialisation, education efforts focusing on equipping the graduates with numerous competences and the graduate profile having been more precisely determined.

Consequently, it seems necessary to reflect on the factors determining the operation of Polish higher education institutions in the country's current socio-economic and cultural situation. This article aims therefore to present some reflections on the key processes which influence the operation of higher education institutions and on what their impact is. The factors taken into account include: the transformation of the political and economic system, integration with the European higher education area, the market shift of education, evolving social demands towards higher education institutions and society's attitude towards work. The impact of these processes is exemplified by presenting the evolution of the university model. This article is a theoretical discussion and synthesises the existing knowledge on this topic on the basis of a critical review of the literature.

\section{Processes shaping the environment of higher education institutions' activity and their impact}

In today's Poland, the recent profound changes in university education have been fundamentally shaped by the transition from a centrally planned economy to a market economy. This shift has been particularly relevant to education through the most recent transition stage, i.e. the emergence of a knowledge-based economy, making knowledge one of the key factors of economic growth. Although it had always been a necessary element in the economic development, knowledge now features more prominently than ever before, having become one of its foundations. Unlike earlier models of economic growth based on factors of production such as labour, land or capital, the current model treats human knowledge (i.e. skills and qualifications) as the key assurance of the employee's enhanced productivity, adaptability to change and capability of absorbing innovation (MAKULSKA, 2012). Research and development (R\&D) centres have become a crucial element in the structure of large corporations. They determine a company's standing in the market. By climbing the education ladder, people increase their own worth as "knowledge carriers" and their knowledge is a resource giving them a competitive advantage in the labour market. In this situation, there is mostly a demand for qualified labour, while the overall demand for labour is decreasing (SADOWSKI, 2005).

The role of knowledge manifests itself not only in the changed functioning of the economy but also in the transformation of social structures. Education has been found to be the fundamental mechanism of social and economic advance. "Development and transformations occur under the predominant influence of science. The effect of scientific progress is becoming the main factor of economic development, far outweighing other factors" (CHOJNICKI \& CZYŻ, 2006, p. 423). DENEK (2013) has emphasised the role of higher education in this process by voicing his opinion that, in today's social and economic development, university education is what petroleum was for post-industrial society.

A market approach to education can be observed at all educational levels (NIEZGODA, 2011). A major part of the population treats the entire education pathway, from pre-school to university, as a long-term investment, absorbing tangible and intangible resources, aiming to ensure a person's favourable position within the social structure. This strategy manifests itself in the broad spectrum of extra-curricular educational activities which parents choose for their children as early as preschool age and continues through to the school age, by paying for their children's private lessons. Convinced that such efforts are worthwhile and necessary, parents strive to place their offspring in the best possible schools and to make sure that their children finish subsequent education stages with the highest possible test results. They evaluate the quality of education services and perceive the choice of a school as an investment decision. The rationale for making such strenuous efforts, whether or not with the child's acceptance, is the parents' determination to ensure the best possible employability for their child once he or she grows up. In Poland, this is a relatively new phenomenon, which, besides creating a new context for higher education, also greatly increases social stratification.

The free market concept (permeating directly to education from the business context), liberalisation of education, and the competitiveness requirement, have all contributed to transformation within higher education (MUSIAŁ, 2011). In a centrally planned economy, higher education is controlled by the State, which financed its expenditure. There were no reasons for universities to compete other than on purely academic terms, hence their lack of tradition and experience in this respect, or a lack of conviction that such efforts are necessary. Currently, universities must compete in many respects, including mainly for funds for teaching and research, as well as for students willing to 
enrol and for teachers/researchers, and professors in particular. Because of the growing competition between universities, they must, to certain extent, be treated and managed as commercial enterprises (ROMERO \& DEL RAY, 2004; HEMSLEY-BROWN \& OPLATKA, 2006; MARGINSON, 2006). The introduction of market mechanisms into higher education has resulted in the usage of the term "service" in an educational context (DRAPIŃSKA, 2011). This service approach in higher education has been expressed in the Polish Higher Education Act of 27 July 2005, listing "research, development activities, and research services" among the key functions of a higher education institution (Article 13(1)(3)). In a market economy, one of the key factors of the quality of such services is, as also formulated in the Act, "teaching students with a view to preparing them for professional work" (Article 13(1)(1)).

Thus, universities and other higher education institutions compete in the free market as educational service providers (MAZURKIEWICZ, 2012). However, competition between higher education institutions is a particular type of competition, fundamentally different from that between commercial companies and other institutions. Universities are distinct in that higher values and a social mission play (or should play) a significant role in their operation. For that reason, they must not adopt a purely economic strategy, aiming solely at maximising their financial gain. Unlike most other companies, or institutions, universities compete largely in a social dimension. The position of a university in the services market is determined by non-economic factors, such as its reputation, prestige, and the broadly understood expected social status of its graduates.

Competition between universities is becoming fierce as a consequence of increasing difficulties of finding new potential students willing to enrol (Doucouliagos \& AввоTT, 2007). This ever more visible atmosphere of rivalry between universities is evidenced by university rankings, all affecting, to a varying degree, the choices between them made by prospective students. The impact of these rankings on the popularity of a given university or study programme grows with the likelihood of obtaining economic and social benefits from having a degree (MARGinson, 2004, 2006). Competition between universities is particular in that their competitive position cannot be verified as directly and unambiguously as in business, where it is defined by a company's market position (SIWIŃSKI, 2013, p. 130). In the educational services market and in the current economic circumstances, the competitive position of a university is chiefly defined by the situation of its graduates in the labour market (PIRóG, 2014).

Transformation of social structures resulting from the rapid growth of numbers of people going to university also causes changes in the system of social class. Education level is a factor of social stratification, which means that having a university degree should determine a person's high position in the social hierarchy. Education is also a key indicator of a person's adaptability to change, which is a key feature of the evolution of today's society and economy. Adaptability is therefore the optimal response strategy. People who can respond to challenges in the best possible way, i.e. adapt to changes by expanding their own competences and thus be flexible on the labour market, can benefit from the changes. Those who cannot accept and address the changes proactively, lose out. People's ways of confronting changes define social borders (REMBOWSKa, 2013).

People's high determination to obtain a degree and their increased aspirations concerning their career, bound to determine their social standing, have resulted in the rapid growth of the number of degree holders. The resulting surplus of people with high formal competences has disturbed the previously observed and predictable process of graduates moving towards higher social microstructures through access to attractive jobs and pay offers. It has also been one of the causes of increasing unemployment (in all its types) among recent graduates. In market economy countries, unemployment has become a constant structural feature, even among university graduates (KuRZyNowsKi, 2001; FIRLIT-FESNAK \& SZYlKoSKOCZNY, 2008). Globalisation, technological progress and economic, demographic and institutional changes have also had a negative impact on employment. The widespread and long-lasting difficulties with obtaining and keeping a job, and low likelihood of finding one, have become a genuine threat to social stability.

These processes also determine the evolution of work relationships and have a deregulating impact on the labour market. A surplus of degree holders allows employers to formulate excessive requirements for job applicants, to hire them to jobs below their qualifications and to offer low salaries. There is an increase in the use of flexible work arrangements, which allow employers to cut costs but are not always favourable for employees. Flexible work arrangements compromise the employees' social security, limit their professional and social promotion opportunities and means they are unable to plan their career. They result in the emergence 
of new structural organisations and new types of social relations, different than to date.

Another important factor shaping the current environment for universities has been Poland's integration with the European higher education area, involving a phenomenon known as "Bolognisation", largely changing the operating schemes of universities and introducing new concepts of education at this level. Traditionally, university was the local centre of intellectual life, exerting a cultural and educational influence on society at large. Currently the dominating view, particularly in the EU documents, is one of the university being supposed to serve society's practical economic purposes and needs (CHMIELECKA, 2003). The Bologna Declaration puts significant emphasis on the issue of professional careers of university graduates. Member States have been obliged to reform their higher education systems, with a view to increasing their graduates' employability. Also heads of many European universities have pointed out the necessity to care for graduates' successful transition to the labour market (BANASZAK, 2012).

An important element in the process of shaping the new higher education environment has been an evolution in the population's attitude towards work. Not long ago, work was seen mainly as an onerous activity carried out under physical, economic, or institutional constraint. Only recently has work been reinterpreted in the eyes of the Polish population in general as an important element in human and social development and of value in itself. It has increasingly been perceived as meeting inherent human needs, both the basic ones and those higher in the hierarchy (fulfilment of aspirations, satisfaction). Work has become the most important in the hierarchy, as it largely affects the quality of life, particularly when many people have problems finding a job (ŁYSIK, 2011; SALA, 2008).

Nowadays, a person's job has an ever growing influence on their social standing; it determines their development and functioning; it defines their lifestyle and quality of life. Currently, therefore, the key challenge for a person trying to function in their environment is their ability to find their way in the labour market. Whether they are successful or not is the key differentiating, and disintegrating, factor within society. The changes occurring in these three interrelated areas education, labour market and social structures - are dynamic and multifaceted. Growing globalisation processes make volatility the key defining feature of today's work as well as today's economy and society (GIDDENS \& SUTTON, 2012). Some of the defining features of today's jobs are volatility and precarity, but also the need for new and constantly upgraded skills, broad range of tasks, physical strain, and multicultural environment (ŁYSIK, 2011). The high dynamics of the labour market and working conditions result in the introduction of new organisational and substantive arrangements, unfamiliar to the employees, putting them under emotional pressure and demanding high stress resilience from them. The instability of labour markets have made the risk of job loss, or job change, an inherent part of every stage of a professional career today, in every profession. Thus, work stability has largely been replaced by volatility (WoŁK, 2013).

In these circumstances, education has been set to take on an important role in responding to the challenges of the changing world and of social and economic transition in the 21 st century (DELORS, 1998). These mechanisms have brought about changes in the academic education model and the emergence of a new perception by society of education's role in people's efforts to shape their life and in their approach to work and career. In the modern society, education is a crucial factor in social and economic advance; it is decisive for people's access to jobs which could meet their economic and autotelic aspirations. Knowledge has taken on a dual role: as a factor of economic development and as a product. As a product, it is measurable and marketable. Thus, education has assumed an economic value as a capital asset and is treated as an investment, of sorts, in the person's future labour market standing; it is perceived as the cost of placing oneself in a higher social class (SzTOMPKA, 2012). This process has resulted in the rapid growth in the population of an interest in taking up university studies in order to build a "knowledge capital", and a transformation of the university model (Fig. 1).

\section{Evolution of the university model}

The processes outlined above result in constant changes in the economic, social and cultural environments which have always determined the evolution of the university model. The nature of the university as an institution and the teaching it offers were always, and continue to be, determined by contexts: initially, the medieval city; later, the nationstate; and currently, global capitalism (TRZCIONKOWSKI, 2014). The vision of the contemporary university, and consequently higher education in general, is evolving rapidly in line with the requirements of a post-modern society; the scope of research and the education offer are largely a response to the society's needs. There is an emphasis on the "social responsibility of universities" and the need to 
transform them into institutions serving their environment (LEJA, 2008).

These social and economic considerations and the pressure of globalisation have brought about a transformation of the university from the Cartesian to the post-Cartesian model, both in Poland and elsewhere (JAŁOWIECKI, 1998). According to the former model, scientific and academic endeavours are taken up for the sole purpose of cognition and for the inside purposes of the academic community. Research is done within clearly demarcated disciplines; members of research teams work in their own isolated hierarchical structures and evaluate the effects of their research within their own milieu.

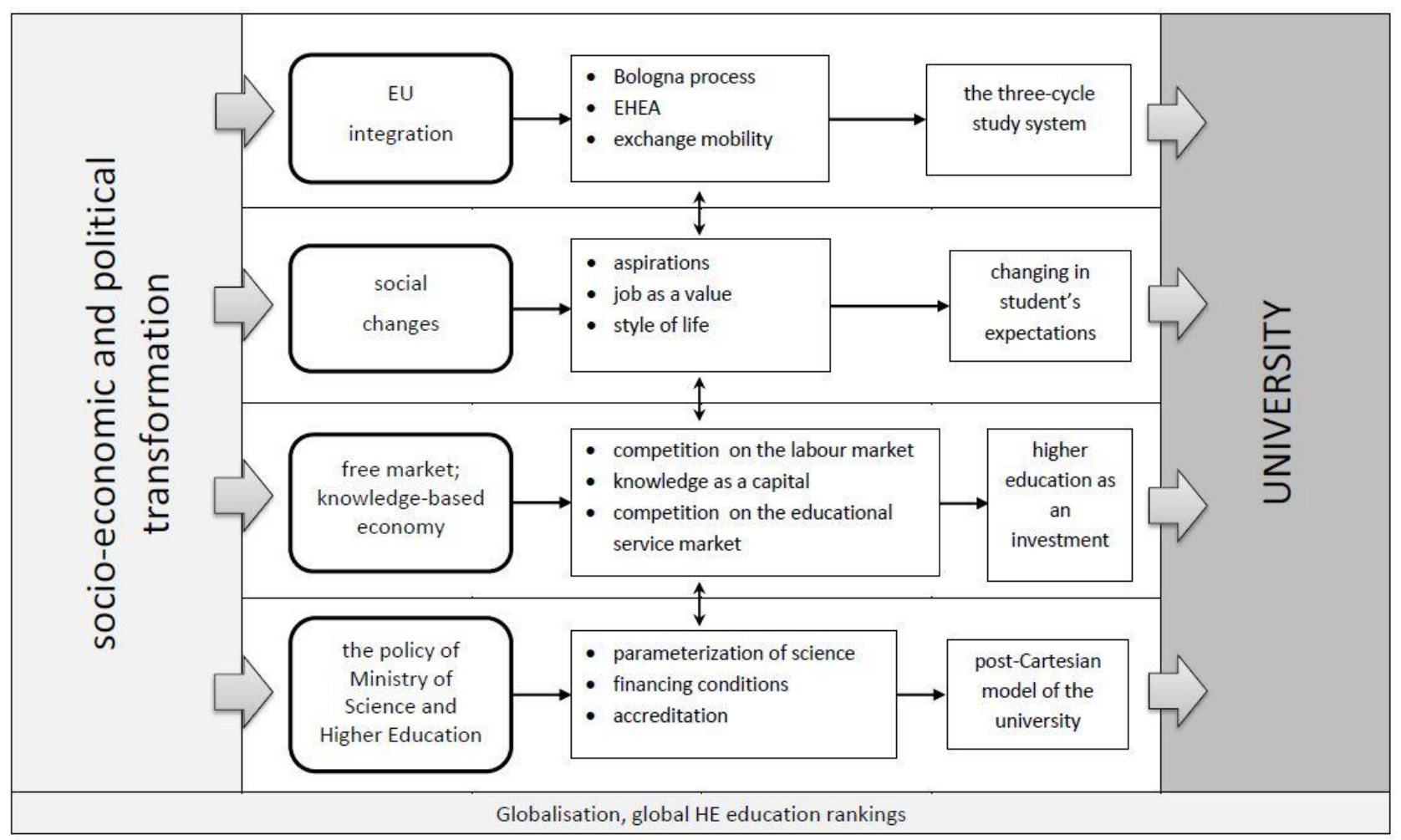

Fig. 1. Processes determining the operation of the university in the 21st century (author's own work)

In the post-Cartesian model, the value of science lies in its applicability, and the results and findings of research are targeted at specified recipients. The focus is being shifted from internal towards external purposes, which consist in meeting the society's demands. The multitude of these demands and the complexity of social considerations necessitate interdisciplinary research. Borderline disciplines are starting to develop. This, in turn, is changing the model of interconnections between researchers, from a vertical to a horizontal hierarchy, as international cooperation is becoming important. Building international teams of researchers and experts is part of creating a uniform education system (e.g. in the EU). Those occurrences create the demand, and the environment, for the emergence of competences which are far more diverse than to date, among both researchers and students. This model of higher education means that new relations between academia and business, or between universities and various public institutions, should come into being.

\section{Conclusion: the challenges}

The main task of education in the $21^{\text {st }}$ century has become not only shaping personalities but, most of all, helping people to overcome obstacles and to adapt to the fast development pace of today's world. This point of view on social change reveals the new challenges and tasks which education is facing. It also defines the direction in which the entire education system, including higher education, should evolve. Universities have an important role to play in educating young people and offering continuing education to adults.

Young people, attending all types of study cycles, have been empirically shown to expect that the studies will give them profound knowledge in the chosen discipline and also help them secure an attractive job. On the other hand, adults, often highly experienced in professional work, who decide to enrol onto postgraduate courses, do not usually expect the university to give them an opportunity of intellectual development as a value in itself but 
rather to help them solve, at least partially, specific problems they have encountered in their environment and meet the requirements of their workplace. Hence, universities should create an educational offer which will meet the demands of both these groups of students, thus developing appropriate quality standards of their educational services (PIRÓG, 2015).

Changes in study curricula (including in geography degree programmes) often seem to be made on the basis of intuition, without a profound verification of how well they equip young people for adult life. Solutions introduced in this way, aiming to facilitate the graduates' successful career, are often brutally proven futile by the reality of the labour market. The higher education model that has prevailed in Poland to date, including in geography education, does not seem to match the evolving social and economic situation in the labour market. A commitment to ensure a smooth and satisfactory university-to-work transition is an important component in developing high quality education. It also helps improve the status of the given degree programme in the educational services market. It is not so much about ensuring "training in accordance with the labour market demands", as those demands varying by area and changing over time much more rapidly than the educational system could be modified to suit them. Also, preparing students for professional careers, important though it is as an objective of university training, is not the only objective. Rather, universities should develop a certain constant awareness, not so much of the needs, but of the characteristics of the labour market and the dynamic changes it undergoes. That awareness should manifest itself in practical thinking, and in academic theories being constantly checked against real life problems. According to research, that process should encompass the following elements:

1) a cyclical examination of the adopted education patterns through audits of plans and curricula of degree programmes and their consequent updates,

2) constant implementation of innovations in teaching, and preparing future graduates to new job types,

3) shaping a positive image of the given university or degree programme,

4) holistic support for students in their efforts to plan and start their careers.

In an increasingly competitive environment, both in the labour market and in the educational services market, it will also be crucial to develop good relationships with stakeholders in the universities' surrounding. It is also important to make sure that those stakeholders continue - or start - to believe that geography graduates are equipped with a range of competences which make them competitive employees and which facilitate their smooth entry into the labour market, allowing them to achieve a relatively high social standing and translating into a higher quality of life in the region.

\section{References}

Banaszak B. 2012. Zatrudnialność absolwentów w procesie bolońskim. Forum Akademickie, 9: 23-25.

Chmielecka E. 2003. Rola uniwersytetu w społeczeństwie wiedzy. Uwagi na marginesie dokumentów Unii Europejskiej. [in:] Osiński J. (ed.) Wzrost gospodarczy i rozwój społeczny jako paradygmaty współczesności. SGH, Warszawa.

Chojnicki Z., Czyż T. 2006. Aspekty regionalne gospodarki opartej na wiedzy w Polsce, Bogucki Wyd. Nauk., Poznań.

Dach Z. 2008. Przemiany współczesnych rynków pracy. Zesz. Nauk.. Polskie Tow. Ekon., 6: 249-263.

Delors J. 1998. Edukacja. Jest w niej ukryty skarb. Raport dla UNESCO Międzynarodowej Komisji do Spraw Edukacji dla XXI wieku. SOP, Wyd. UNESCO, Warszawa.

Denek K. 2013. Uniwersytet. Między tradycją a wyzwaniami współczesności i przyszłości. Edukacja Humanistyczna, 1(28): 7-21.

Doucouliagos Ch., Abbott M. 2007. Competition and Efficiency: Overseas students and technical efficiency in Australian and New Zealand universities. School Working Paper Economic Series, 9, Faculty of Business and Law, 1-36.

Drapińska A. 2011. Zarządzanie relacjami na rynku usług edukacyjnych szkół wyższych. PWN, Warszawa.

Firlit-Fesnak G., Szylko-Skoczny M. (ed.) 2008. Polityka społeczna. PWN, Warszawa.

Gęsicki J. 2013. Dokąd zmierza świat nauki i edukacji? [in:] Plewka Cz. (ed.) Nauka, edukacja, rynek pracy. Przede wszystkim współdziałanie. Szczecin-Koszalin: 43-48.

Giddens A., Sutton, P.W. 2012. Socjologia. Wydanie nowe. PWN, Warszawa.

Hemsley-Brown J.V., Oplatka I. 2006. Universities in a competitive global marketplace: a systematic review of the literature on higher education marketing. Int. J. Public Sector Manage.,19(4): 316-338.

Jałowiecki B. 1998. Rola uniwersytetu w rozwoju regionalnym. Zagadnienia Naukoznawstwa, 4(138): 552.

Kurzynowski A. (ed.) 2001. Polityka społeczna. Wyd. SGH, Warszawa.

Leja K. 2008. Uniwersytet organizacją służącą otoczeniu. [in:] Leja K. (ed.) Społeczna odpowiedzialność uczelni, Wyd. Politechnika Gdańska, Gdańsk: 53-72.

Lisowski A. 2008. Geografia społeczna. [in:] Jackowski A., Liszewski S., Rychling A. (eds.) Historia geografii polskiej. PWN, Warszawa: 195-205.

Lisowski A. 2012. O miejscu geografii społeczno-ekonomicznej w geografii i systemie nauki. Prz. Geogr., 84(2): 171-198.

Łysik K. 2011. Wpływ gospodarki informacyjnej na pracę $\mathrm{i}$ pracowników współczesnych organizacji. Edukacja Ekonomistów i Menedżerów. Problemy. Innowacje. Projekty, $3(21)$.

Makulska D. 2012. Kluczowe czynniki rozwoju w gospodarce opartej na wiedzy. [in:] Stacewicz J. (ed.) Pomiędzy polityką stabilizacyjną a polityką rozwoju. Prace i Mat. Inst. Rozwoju Gospodarczego SGH, 88,: 169-194.

Marginson S. 2004. Competition and markets in higher education: a "glonocal" analysis. Policy Futures in Education, 2(2): 175-244. 
Marginson S. 2006. Dynamics of national and global competition in higher education. Higher Education, 52: 1-39.

Mazurkiewicz G. (ed.) 2012. Jakość edukacji. Różne perspektywy. Wyd. UJ, Kraków.

Musiał G. 2011. Społeczne uwarunkowania procesu kształcenia XXI wieku. [in:] Jędralska K., Bernais J. (eds.) 2011. Kompetencje absolwentów studiów ekonomicznych. Perspektywa nauki i biznesu, Wyd. Uniw. Ekon. w Katowicach, Katowice: 112-131.

Niezgoda M. (ed.) 2011. Społeczne skutki zmiany oświatowej w Polsce. Wyd. UJ, Kraków.

Piróg D. 2014. Konkurowanie uniwersytetów na rynku usług edukacyjnych w warunkach kryzysu gospodarczego i nasilających się trudności tranzycji absolwentów. Prace Komisji Geogr. Przemysłu PTG, 28: 117-130.

Piróg D. 2015. Przechodzenie absolwentów studiów geograficznych na rynek pracy. Proces, czynniki, predykcja. Prace Monogr. 715. Wyd. Uniw. Pedagogicznego im. Komisji Edukacji Narodowej, Kraków.

Plewka Cz. 2013. Refleksje nad potrzebą powiązania rynku pracy z nauką i edukacją. [in:] Plewka Cz. (ed.) Nauka, edukacja, rynek pracy. Przede wszystkim współdziałanie. Szczecin-Koszalin: 73-96.

Rembowska K. 2013. Integracja i dezintegracja społecznoprzestrzenna. Współczesny wymiar problemu. [in:] Wójcik M. (ed.) Studia regionalne. Społeczeństwo - region - miejsce. Wyd. UŁ, Łódź: 59-69.

Romero L., del Rey E. 2004. Competition Between Public And Private Universities: Quality, Prices And Exams. Economics Working Papers, 046423, Univ. Carlos III, Departamento de Economía.
Sadowski Z. 2005. Transformacja i rozwój. Wybór prac. Wyd. Polskiego Tow. Ekon., Warszawa.

Sala S. 2008. Wpływ procesów globalizacji na czas i miejsce pracy. [in:] Maik W., Rembowska K., Suliborski A. (eds.) Terytorium, region, miejsce - czas i przestrzeń w geografii. Wyd. WSG, Bydgoszcz: 155-164.

Siwiński W. 2013. Nowa misja uniwersytetów: zdolność konkurowania. [in:] Woźnicki J. (ed.) Misja i służebność uniwersytetu $w$ XXI wieku. Inst. Społeczeństwa Wiedzy Fundacji Rektorów Polskich, Warszawa: 127-132.

Suliborski A., Wójcik M. 2011. Rola i miejsce edukacji geograficznej we współczesnym świecie. [in:] Kostrzewski A., Maik W., Brudnicki R. (eds.) Geografia wobec problemów współczesności. Funkcje poznawcze i praktyczne geografii. WSG w Bydgoszczy: 79-92.

Sztompka P. 2012. Socjologia. Analiza społeczeństwa. Wyd. Znak, Kraków.

Tracz M., Hibszer A. 2013. Geography studies in Poland after 1989 - selected issues. Miscellanea Geographica Regional Studies on Development, 17 (3): 19-25.

Trzcionkowski L. 2014. Zanim narodził się uniwersytet. Niezbędnik Inteligenta, 4: 6-10.

Ustawa (Ustawa, 2005) z dnia 27 lipca 2005 r. Prawo o szkolnictwie wyższym, Dz.U. nr 164, poz. 1365 z późniejszymi zmianami.

Wołk Z. 2013. Zbieżność przygotowania do życia i do pracy w warunkach płynnej rzeczywistości. [in:] Plewka Cz. (ed.) Nauka, edukacja, rynek pracy. Przede wszystkim współdziałanie, Szczecin-Koszalin: 55-64.

Woźnicki J. 2008. Inwestowanie w kapitał ludzki i rozwój sektora wiedzy w Polsce. Nauka, 1: 151-165. 